\title{
Strategi, Aplikasi dan Pengembangan Kecerdasan Emosional dan Spiritual Santri Lembaga Tinggi Pesantren Luhur Malang
}

\author{
Yahya \\ yahyaahaf@gmail.com
}

\author{
Yusuf Ratu Agung \\ ratuagung1@gamil.com
}

Muh.Anwar Fu'ady

anwar_fuady@psi.uin-malang.ac.id

Fakultas Psikologi, Universitas Islam Negeri (UIN) Maulana Malik Ibrahim Malang, Indonesia

\begin{abstract}
Abstrak
Penelitian ini bertujuan untuk mengetahui Strategi, Aplikasi dan Pengembangan Kecerdasan Emosional dan Spiritual di pesantren. Mengingat betapa pentingnya kedua kecerdasan tersebut dalam menentukan kesuksesan seseorang dalam menjalani kehidupan di masa depan. Penelitian ini menggunakan pendekatan kualitatif. Subyek peneltian ini adalah santri di Lembaga Tinggi Pesantren Luhur yang keseluruhan santrinya adalah mereka yang sedang melanjutkan pendidikan di level perguruan tinggi. Tehnik pengumpuan data yang digunakan dalam penelitian ini adalah observasi, wawancara dan dokumentasi. Hasil dari penelitian ini menunjukkan bahwa Lembaga Tinggi Pesantren Luhur Malang menerapkan pengembangan kecerdasan spiritual dan emosional melalui beberapa kegoiatan pesantren diantaanya adalah JQH, dan FORKAFI, diamana dengan kegiatan tersebut diharapkan santri memahami dan menjalankan isi yang ada dalam al-Qur'an yang akan menjadi penuntun dalam menjalankan tanggung jawab dalam kehidupan sehari-hari, karena dalam al-Qur'an dianjurkan untuk berlaku jujur dan melakukan pengabdian kepada masyaraka. Kegiatan pengembangan kecerdsan emosional berupa kegiatan halaqoh. Kegiatan halaqoh ini dengan memberikan beberapa materi lintas disiplin ilmu yang mana dalam materi tersebut akan memberikan pemahaman keilmuan yang menyeluruh sehingga setiap santri akan memiliki satu kesatuan kemampuan emosional dan personal, yang mana dalam materi tersebut diatas sangat relevan dengan kehidupan sehari-hari.
\end{abstract}

Kata Kunci : Santri; Kecerdasan emosional dan Spiritual

Psikoislamika : Jurnal Psikologi dan Psikologi Islam (JPPI) Volume 15. Nomor 2, Tahun 2018. copyright (C) 2018. Pusat Penelitian dan Layanan Psikologi.

\section{Pendahuluan}

Pesantren merupakan sistem pendidikan yang pertama dan tertua di Indonesia, namun terdapat asumsi yang sangat disayangkan mengenai pesantren, diantaranya adalah mutu pengajar dan materinya, hasil yang didapat setelah siswa keluar dari pesantren atau masa depan setelah kelulusan yang dianggap tidak produktif, serba tanggung. Hal ini terbukti masih dominannya lulusan pesantren dalam soal keagamaan.
Berdasarkan fenomena yang ada di masyarakat kita memang kebanyakan pesantren mengajarkan beberapa materi keagamaan. Hal ini memang berdasar pada materi kajian-kajian yang hanya meliputi ilmu-ilmu agama islam seperti nahwu shorof, fiqh, aqidah, serta akhlaq dan tasawwuf. Kemudian pada awal abad ke-20 mencoba mengembangkan diri dengan tuntunan masyarakat yaitu dengan banyak munculnya "anak pesantren" yang berupa lembaga pendidikan madrasah (Djamil, et.al, 1999). 
Model pendidikan pesantren sebagaimana yang telah dijelaskan diatas lebih mementingkan bagaimana mengasah kecerdasan spiritual (SQ), karena dengan mengasah SQ, seseorang akan mampu mengoptimalakan kecerdasan yang lain. Kecerdasan spiritual memungkinkan seseorang untuk berpikir kreatif, berwawasan jauh, membuat atau bahkan mengubah aturan, yang membuat orang tersebut dapat bekerja lebih baik. Zohar dan Marshal (2001) mengatakan bahwa kecerdasan spiritual mampu menjadikan manusia sebagai mahluk yang lengkap secara intelektual, emosional dan spiritual.

Hal senada disampaikan oleh Nggermanto (2002) yang mendefinisikan kecerdasan spiritual sebagai kecerdasan manusia yang digunakan untuk berhubungan dengan Tuhan. Potensi SQ setiap orang sangat besar dan tidak dibatasi oleh faktor keturunan, lingkungan atau materi lainnya. Sementara Ginanjar (2005) dalam bukunya Rahasia sukses membangun kecerdasan emosional dan spiritual berdasarkan 6 rukun Islam dan 5 rukun Iman, dapat difahami bahwa kualitas kecerdasan intelektual individu bukanlah faktor utama yang mempengaruhi keberhasilan individu dalam meraih kesuksesan hidup. Namun faktor yang lebih dominan yang mampu mempengaruhi keberhasilan (kesuksesan) individu adalah kecerdasan emosional.

Kecerdasan emosional ini sangat mempengaruhi kehidupan seseorang secara keseluruhan mulai dari kehidupan dalam keluarga, pekerjaan, sampai interaksi dengan lingkungan sosialnya. Oleh karena itu kecerdasan emosional berpengaruh pada cara seseorang menyelesaikan masalah dalam kehidupan sehari-hari, baik dalam kehidupan keluarga, pekerjaan, maupun interaksi dengan lingkungan sosialnya.

Hasil dari penelitian jangka panjang terhadap 95 mahasiswa Harvard lulusan tahun 1940-an. Puluhan tahun kemudian, mereka yang saat kuliah dulu mempunyai kecerdasan intelektual tinggi, namun egois dan kuper, ternyata hidupnya tidak terlalu sukses (berdasar gaji, produktivitas, serta status bidang pekerjaan) bila dibandingkan dengan yang kecerdasan intelektualnya biasa saja tetapi mempunyai banyak teman, pandai berkomunikasi, mempunyai empati, tidak temperamental sebagai manifestasi dari tingginya kecerdasan emosi, sosial dan spiritual (Yosep, 2005).
Winkel (dalam Wahyu, 2008) menyatakan bahwa kecerdasan emosional menentukan seberapa baik seseorang menggunakan keterampilan-keterampilan yang dimilikinya, termasuk keterampilan intelektual.Kesulitan belajar yang dicirikan oleh menurunnya prestasi belajar sebagai bentuk kegagalan bisa berkaitan dengan dominan afektif, misalnya situasi emosi akan mempengaruhi belajar.

Di sisi lain Nugroho (2004) (dalam Ananto, 2010) menyatakan bahwa pembelajaran yang hanya berpusat pada kecerdasan intelektual tanpa menyeimbangkan sisi spiritual akan menghasilkan generasi yang mudah putus asa, depresi, suka tawuran bahkan menggunakan obat-obat terlarang, sehingga banyak mahasiswa yang kurang menyadari tugasnya sebagai seorang mahasiswa yaitu tugas belajar. Kurangnya kecerdasan spiritual dalam diri seorang mahasiswa akan mengakibatkan mahasiswa kurang termotivasi untuk belajar dan sulit untuk berkonsentrasi, sehingga mahasiswa akan sulit untuk memahami suatu mata kuliah. Sementara itu, mereka yang hanya mengejar prestasi berupa nilai atau angka dan mengabaikan nilai spiritual, akan menghalalkan segala cara untuk mendapakan nilai yang bagus, mereka cenderung untuk bersikap tidak jujur seperti mencontek pada saat ujian. Oleh karena itu, kecerdasan spiritual mampu mendorong mahasiswa mencapai keberhasilan dalam belajarnya karena kecerdasan spritual merupakan dasar untuk mendorong berfungsinya secara efektif kecerdasan intelektual (IQ) dan kecerdasan emosional (EQ).

Berdasarkan latar belakang tersebut, sangat menarik bagaimana Strategi, Aplikasi dan Pengembangan Kecerdasan Emosional dan Spiritual di pesantren. Mengingat bagaimana pentingnya kedua kecerdasan tersebut menentukan bagaimana kesuksesan seseorang dalam menjalani kehidupan di masa depan.

\section{METODE PENELITIAN}

Penelitian ini menggunakan pendekatan kualitatif. Peneliti memilih menggunakan metode ini dengan pertimbangan bahwa kasus yang diteliti merupakan sesuatu yang memerlukan menggunakan pengamatan dan bukan menggunakan model pengangkaan.

Pengambilan subyek dalam penelitian ini dilakukan dengan purposive, yang bertujuan 
untuk mengambil subyek bukan berdasarkan pada strata, random atau daerah, tetapi didasarkan atas tujuan tertentu (Arikunto, 2002). Subyek peneltian ini adalah santri di Lembaga Tinggi Pesantren Luhur yang keseluruhan santrinya adalah mereka yang sedang melanjutkan pendidikan di level perguruan tinggi. Peneliti mengambil subyek di Lembaga Tinggi Pesantren Luhur Malang dikarenakan Pesantren ini selain memberikan pembelajaran keagamaan juga memberikan pengajaran sebagaimana di perguruan tinggi yang disebut dengan halaqoh ilmiah.

Tehnik pengumpuan data yang digunakan dalam penelitian ini adalah observasi, wawancara dan dokumentasi. Analisis data dilakukan untuk mencari sekaligus menemukan jawaban terhadap pertanyaan penelitian, isu-isu penelitian, atau permasalahan penelitian (Koentjoro, 2007). Adapun prosedur analisis data dimulai dengan deskripsi tentang pengalama peneliti terhadap fenomena, membuat pertanyaan untuk diajukan dalam interview, dan pengelompokkan kedalam unit-unit makna. Sementara langkah-langkah dalam proses melakukan intepretasi data yang akan diakukan dengan membuat refleksi berdasarkan deskripsinya sendiri dengan menggunakan deskripsi structural (imaginative variation), membuat deskripsi keseluruhan dari makna dan esensi dari pengalaman., dan membuat composite textural-structural description dari makna-makna dan esensi pengalaman, lalu mengintegrasikan semua deskripsi struktural individu menjadi deskripsi universal dari pengalaman yang mewakili responden secara keseluruhan (Moustakas, 1994). Adapun kriteria yang digunakan dalam pemeriksaan data berdasarkan ketekunan pengamatan, triangulasi, pengecekan sejawat, uraian rinci, dan kecukupan referensi

\section{HASIL DAN DISKUSI}

Nama Lembaga Tinggi Pesantren Luhur Malang (LTPLM) merupakan nama yang dilahirkan oleh organisasi Islam se-Indonesia. Ciri pokok dari Lembaga Tinggi Pesantren Luhur Malang adalah mendalami kitab-kitab salafiyah dan memiliki kiprah yang juga diperankan oleh perguruan tinggi, yaitu menjalankan Tri Darma Perguruan Tinggi.

Lembaga Tinggi Pesantren Luhur Malang yang terletak di Jalan Sumbersari nomer 88 Malang tentunya mendukung aktivitas santri yang juga senagia besar dari meraka adalah mahasiswa dan mahasiswi dari berbagai universitas seperti Universitas Brawijaya, Universitas Negeri Malang, Universtas Merdeka, Universitas Muhammadiyah Malang, Unvrsitas Islam Malang, Wearness, POLINEMA, POLTEKKES, dan UIN Maulana Malik Ibrahim Malang. Pesantren Luhur Malang ini memiliki semboyan yang sering disampaikan oleh pengasuh yaitu triple Co (Coownership, Codetermination, Corespon-sibility)

Sebelum menjadi santri di Pesantren Luhur Malang calon santri harus melalui seleksi yang dilaksanakan oleh pengurus di Lembaga Tinggi Pesantren Luhur Malang. Seleksi masuk ini dimaksudkan untuk melakukan penjaringan yang dilaksanakan setiap tahun. Adapun kapasitas santri yang diterima akan disesuaikan dengan jumlah kamar yang tersedia di Lembaga Tinggi Pesantren Luhur Malang. Tes yang digunakan dalam seleksi penerimaan santri bari di Lembaga Tinggi Pesantren Luhur Malang adalah tes membaca kitab, tes pengetahua umum, tes dan membaca a-Qur'an.

Suasana yang membedakan antara Lembaga Tinggi Pesantren Luhur Malang dengan pesantren lainnya adalah adanya kegiatan istighotsah setiap hari setelah sholat magrib dan sholat subuh, serta halaqoh ilmiah yang dialaksanakan setiap hari setelah menjalankan Solat Subuh. Kegiatan halaqoh ilmiah ini adalah upaya pesantren agar santri memiliki pengetahua yang komprehensif dalam mendalami ilmu-ilmu umum. Hal ini karena materi yang diberikan pada saat halaqoh adalah materi yang terdapat di perguruan tinggi dari berbagai disiplin ilmu. Melalu kegiatan halaqoh ini diharapkan santri memiliki keseimbangan antara ilmu agama dan ilmu umum.

Dalamberbagai kesempatan halaqoh pengasuh Lembaga Tinggi Pesantren Luhur Malang sering menyampaikan bahwa santri yang mendalami ilmu di Lembaga Tinggi Pesantren Luhur Malang selama kurang lebih 4,5 tahun disebut sebagai ahlul ma'had, sementara dan selalu mendapatkan hadiah serta kiriman do'a al fatehah dari santri setiap hari. Sementara santri yang menempuh ilmu di Lembaga Tinggi Pesantren Luhur Malang kurang dari 4,5 tahun disebut alumni.

\section{A. Analisis dan Pembahasan}


Berdasarkan hasil yang ditemukan dilapangan, Lembaga Tinggi pesantren luhur dalam perjalanannya memliliki metode dan cara tersendiri yang tentunya berbeda dengan pesantren salafi pada umumnya. Pesantren Luhur, selain mengembangkan kecerdasan spiritual yaitu melalui pengkajian-pengkajian salafi juga melakukan pengembangan kecerdasan spiritual dengan melakukan kegiatan-kegiatan yang memfasilitasi pengembangan bakat dan minat santri.

Lembaga Tinggi Pesantren Luhur Malang (LTPLM) memliki ciri yang berbeda dengan pesantren salafiyah pada umumnya. Suasana yang membedakan antara Lembaga Tinggi Pesantren Luhur Malang dengan pesantren salafi lainnya adalah terdapat kegiatan halaqoh ilmiah yang dilaksanakan setiap hari setelah melaksanakan sholat subuh dan istighotsah. Kegiatan Halaqoh yang dilaksanakan inilah yang membuat santri LTPLM tidak hanya belajar ilmu agama sebagai pendukung kecerdasan spiritual, akan tetapi juga ilmu umum untuk meningkatkan kecerdasan emosional, sehingga ilmu yang dipelajari dapat seimbang antara kecerdasan spiritual dan kecerdasan smosional. Ciri-ciri yang disebutkan diatas sama dengan cirri-ciri salafi yang ada di Pesantren Luhur, yang mana banyak melakukan banyak hal di bidang pengajaran seperti kajian kitab kuning yang biasa dikaji oleh pesantren-pesantren salafiyah pada umumnya, karena santri belajar di pesantren ini merupakan mahasiswa lulusan madrasah aliyah atau sederajat.

Adapun kegiatan pengajian kitab yang terdapat di Lembaga Tinggi Pesantren Luhur Malang dilaksanakan setiap hari Senin - Jum'at. Pengajian kita tersebut dilaksanakan setiap selesai solat ashar dan setelah sholat maghrib. Adapun beberapa kitab yang dikaji diantaranya: Tafsir Jalalain, Minhajul 'Abidin, Mau'idhlotul Mu'minin, Jawahirul Balaghoh, , Husnul Hamidiyah, Subulus salam, Tadzhib, Asybah Wan-Nadhoir, Qomi'ut Tughyan, Al-Luma', , Dahlan Alfiyah, Kawakibud-duriyyah, Ibnu 'Aqil, Tafsir Ayatul Ahkam, Irsyadul 'Ibad, Daqoiqul Akhbar, Riyadhus Sholihin, Hasyiah Abi Jamroh, Syarhul Hikam dan Durrotun Nashihin.

Dari beberapa kajian kitab tersebut diatas, kebanyakan kitab-kitab yang mengkaji tentang pendalaman agama islam, seperti pada kitab syarhul hikam. Kitab al-Hikam ini berisi aforisme-aforisme Ibnu Atha'illah sebagai pengarang kitab yang mengajarkan banyak nasihat kepada pembacaya agar setiap waktu selalu dekat dengan Sang Pencipta, Allah Swt.

Sebagaimana yang dikatakan oleh Agustian (2008) bahwa orang yang memiliki kecerdas secara spiritual dalam kehidupan sehari-hari, senantiasa berperilaku yang baik, atau berakhlakul karimah. Perilaku baik yang bisa ditemui pada santri pesantren luhur seperti seperti sifat istiqomah, kerendahan hati, tawakkal (berusaha dan berserah diri), keikhlasan (ketulusan), kaffah (totalitas), tawazzun (keseimbangan), ihsan (integritas dan penyempurnaan).

Beberapa sifat tersebut peneliti temui dilapangan, seperti istiqomahnya santri mengikuti setiap kegiatan yang dilaksanakan oleh pesantren bukan karena mereka takut mendapatkan hukuman yang diterapkan tetapi karena mereka sadar bahwa apa yang akan dilakukan akan bermanfaat bagi santri sendiri untukmasa yang akan datang.

Sifat kaffah (totalitas) merupakann suatu sifat keikhlasan yang mendalam akan seni peran yang sedang dan harus dijalani, keterlibatan yang penuh, hati yang tanpa batas untuk menyelesaikannya, tanpa pamrih, tanpa mengharapkan prasyarat apapun. Hal ini bisa dilihat dari sifat totalitas santri pesantren luhur dalam menjalani kegiatan maupun aktifitasaktifitas lain diluar pesantren.

Totalitas-totalitas santri pesantren luhur tidak perlu diragukan lagi karena mereka memiliki motto tripell Co (Co ownership, Co determination, Co responsibility). Adapun makna dari slogan triple Co (Co ownership, Co determination, Co responsibility) adalah setiap santri harus bertanggungjawab terhadap pesantren,terhadap agama ,terhadap Allah dan rasul-Nya dan terhadap dirinya sendiri, merasa memiliki sehingga menjaga,dan menentukan atau punya inisiatif untuk melakukan hal yang baik.

Motto lain yang dimiliki oleh pesantren luhur adalah "My soceity is my university" yang mana masyarakat pesantren adalah merupakan masyarakat universitas karena santri di pesantren Luhur terdiri dari mahasiswa-mahasiswa yang berasal dari universitas-universitas yang ada di Malang,dari berbagai fakultas dan jurusan, sehingga kehidupan di pesantren seperti kehidupan di universitas dalam hal keilmuan. Hal ini akan membuat santri menjadi lebih kaya akan keilmuan yang dimiliki sehingga nantinya memiliki pengetahuan yang komprehensif ketika benar-benar sudah terjun ke masyarakat. 
Slogan yang berikutnya ini adalah moto yang sangat sesuai dengan semua kegitan yang ada di Lembaga Tinggi Pesantren Luhur ini, karena memang semua kegitannya ditujukan untuk menggali ilmu sebanyak-banyaknya, baik ilmu kajian agama tapi juga ilmu-ilmu umum segala bidang yang bermanfaat untuk memperoleh kebahagian dunia dan akhirat, sehingga moto ini cocok untuk dijadikan slogan di pesantren Luhur ini "tiap hari bergemilang dalam lautan ilmu yang berfaedah".

Berdasarkan temuan data diatas terdapat beberapa factor yang mendorong santri untuk memiliki kecerdasan spiritual yang ada dipesantren luhur diantaranya adalah Jam'iyyatul Qurro' Wal Huffadh (JQH), dan FORKAFI (Forum Kajian Fiqih). Nggermanto (2002) menjelaskan bahwa kecerdasan spiritual adalah kecerdasan manusia yang digunakan untuk berhubungan dengan Tuhan. Potensi SQ setiap orang sangat besar dan tidak dibatasi oleh faktor keturunan, lingkungan atau materi lainnya. Di pesantren Luhur JQH ini berupaya untuk menjadi wadah para pecinta al-Qur'an di pesantren yang diharapkan santri Pesantren Luhur mampu memberikan kontribusi bagi agama dan masyarakat kelak nantinya. Selain itu JQH Pesantren Luhur ini adalah untuk membentuk mahasantri yang menghafal, memahami makna dan menjalankan isi dari Al-qur'an, sehingga bermanfaat bagi agama, nusa dan bangsa. Diharapkan dengan memahami dan menjalankan isi yang ada dalam al-Qur'an maka itu akan menjadi penuntun dalam menjalankan tanggung jawab dalam kehidupan sehari-hari, karena dalam al-Qur'an dianjurkan untuk berlaku jujur dan melakukan pengabdian kepada masyarakat.

Disisi lain juga terdapat Forum Kajian Fiqh (FORKAFI) dilaksanakan dengan format Bahsul Masail yakni terdiri atas moderator, notulen, mushohih, murojih, dan anggota anggota FORKAFI. Kitab yang dijadikan referensi FORKAFI Luhur yaitu kitab I'anatut tholibin, yang mana pendapat dari Imam Rofi'I dan Imam Nawawi yang paling sering diterima. FORKAFI menyeleksi permasalahan yang layak untuk dibahas dan diselesaikan bersama. Tema yang diangkat ketika forum berlangsung wajib dihadiri santri. Dengan demikian sebagaimana pendapat dari ciri- ciri orang yang memiliki kecerdasan spiritual Zohar dan Marshall (2001) dan Sinetar (dalam Rachmi, 2010) Pesantren Luhur memiliki beberapa faktor yang mampu mendukung para santrinya untuk memiliki kecerdasan spiritual yaitu para santri akan memiliki kesadaran terhadap dirinya sendiri, memiliki visi, bersikap fleksibel, berpandangan holistik, melakukan perubahan, menjadi sumber inspirasi, dan mampu refleksi diri sendiri.

Adapun faktor dan fasilitas yang mendukung bagi santri dalam upaya mengembanagkan kecerdasan emosional santri diantara beberapa kegiatan tersebut antara lain adalah Halaqoh, kegiatan Jurnalistik LTPLM, Komunitas Komunikasi Luhur (KaTwoL), forum diskusi LUBAB, Luhur Fotball Club (LFC), dan GiKaPala. Menurut analisis psikologis, kegiatan halaqoh ilmiha yang dilaksnkan di Lembaga Tinggi Pesantren Luhur Malang ini sangat menarik karena kegiatan halaqoh yang dilaksanakan di pesantren ini sangat jauh berbeda dengan yang ada di pesantren pada umunya. Kegiatan halaqoh yang biasa dilakukan di pesantren salafi adalah kegiatan halaqoh yang berkaitan dengan pengembangan spiritual santri dengan membahas hal-hal yang berkaitan dengan keagamaan seperti al-Qur'an, Hadist, fiqh, akidah dan sebagainya. Sedangkan di Pesantren Luhur kegiatan halaqoh ini juga berkaitan dengan kemajuan sain dan teknologi dan perkembangan manusia yang ada pada saat ini.

Halaqoh ini menjadi menarik ketika membahas hal-hal lain yang dipresentasikan oleh masing-masing santri sesuai dengan fakultas dan jurusan yang diambil. Sehingga santri Pesantren Luhur ini akan mendapatkan pengetahuan yang komprehensif dalam menjalani kehidupan kelak di masyarakat masing masing.

Adapaun materi yang diberikan dalam kegiatan halaqoh adalah sebagai berikut:

Tabel 1

Judul halaqoh LTPLM

\begin{tabular}{|c|c|}
\hline No & Judul Halaqoh \\
\hline 1 & $\begin{array}{l}\text { Dhilalah Muthobaqoh, Iltizam dan } \\
\text { Tadhommun }\end{array}$ \\
\hline 2 & $\begin{array}{l}\text { Apa yang dimaksud dengan 'Continous } \\
\text { Progress' dalam Pendidikan }\end{array}$ \\
\hline 3 & بأعيننا و لتصنع على عيني \\
\hline 4 & الخصوص هل يبقى العموم \\
\hline 5 & $\mathrm{H} 2 \mathrm{SO} 4$ dengan air destilasi \\
\hline 6 & $\begin{array}{l}\text { Sebutkan } 5 \text { elemen kompetensi SK } \\
\text { Mendiknas No. } 045 / 2002\end{array}$ \\
\hline 7 & Tugas guru dalam pendekatan SCL \\
\hline 8 & Bentuk-bentuk pengangaguran \\
\hline
\end{tabular}




\begin{tabular}{|c|c|}
\hline 9 & شضية منفية منفلة \\
\hline 10 & $\begin{array}{l}\text { Sebutkan } 3 \text { sistem hukum pidana di } \\
\text { dunia }\end{array}$ \\
\hline 11 & مل هل بجعل كا \\
\hline 12 & Jelaskan motto "non schule set vitae" \\
\hline 13 & Jelaskan kulli dzati dan arodli \\
\hline 14 & $\begin{array}{l}\text { Keuntungan mutlak dan komparatif } \\
\text { dalam dagang }\end{array}$ \\
\hline 15 & $\begin{array}{l}\text { Jelaskan motto hukum belanda "het } \\
\text { recht hink achter de faiten aan" }\end{array}$ \\
\hline 16 & $\begin{array}{l}\text { Contoh-contoh tindakan } \\
\text { penyalahgunaan wewenang(minimal 7) }\end{array}$ \\
\hline 17 & Jelaskan hakekat bahasa \\
\hline 18 & $\begin{array}{l}\text { Pengeterapan hak asasi dalam } \\
\text { kehidupan sehari-hari di Indonesia }\end{array}$ \\
\hline 19 & $\begin{array}{l}\text { Jelaskan secara filosofis eksistensi dan } \\
\text { esensi }\end{array}$ \\
\hline 20 & 3 vernunft menurut Kant \\
\hline 21 & Pandangan sufi tentang manusia \\
\hline 22 & $\begin{array}{l}\text { Orang-orang yang tidak kuasa } \\
\text { melakukan tindakan hukum sendiri }\end{array}$ \\
\hline 23 & $\begin{array}{l}\text { Apa arti ucapan "setiap events tidak } \\
\text { hanya merupakan ringkasan diakron, } \\
\text { tetapi juga ringkasansingkron" }\end{array}$ \\
\hline 24 & $\begin{array}{l}\text { Jelaskan ISP dalam hubungannya } \\
\text { dengan internet }\end{array}$ \\
\hline 25 & Perbedaan zakat dengan pajak \\
\hline 26 & $\begin{array}{l}\text { Jelaskan perbedaan tenaga kerja } \\
\text { manusia dengan pekerjaan tenaga mesin }\end{array}$ \\
\hline 27 & $\begin{array}{l}3 \text { peranan psikologi dalam bidang } \\
\text { hukum }\end{array}$ \\
\hline
\end{tabular}

Sumber: Co.Devisi Halaqoh dan Litbang

Berdasarkann tabel tersebut diatas sebagaimana yang dijelaskan oleh Bar On (Mayer, et al., 2001) bahwa kecerdasan emosional adalah satu kesatuan dari kemampuan emosional, personal, dan sosial yang membantu seseorang untuk beradaptasi dengan tuntutan hidup seharihari. Adanya beberapa materi tersebut diatas menjelaskan bahwa setiap santri akan memiliki satu kesatuan kemampuan emosional dan personal, yang mana dalam materi tersebut diatas sangat relevan dengan kehidupan sehari-hari.

Santri yang juga menempuh pendidikan di universitas sekitar pesantren sepertu Universitas Islam Negeri (UIN) Maulana Malik Ibrahim Malang, Universitas Brawijaya (UB), Universitas
Islam Malang (UNISMA), Universitas Negeri Malang (UM) dan lain-lainnya tidak hanya menekuni keilmuan yang selama ini diambil di fakultas dan jurusan, tapi juga memiliki pengetahuan yang luas dan komprehensif.

Adanya pengetahuan yang komprehensif akan membuat santrimemiliki satu kesatuan dari kemampuan emosional, personal, dan sosial yang membantu seseorang untuk beradaptasi dengan tuntutan hidup sehari-hari, hal tersebut akan membantu santri memiliki pikiran rasional (akal, intelektual) secara sehat.

Sebagaimana yang dijelaskan Golemen (2003) terdapat lima Lima komponen kecerdasan emosional tersebut adalah sebagai berikut:

1) Pengenalan Diri (Self Awareness) dengan adanya Adanya beberapa materi halaqoh yang diberikan maka santri pesantren luhur seperti materi-materi psikologis akan membuat santri memiliki kesadaran emosi dan mampu menilai diri secara teliti (accurate self awareness).

2) Pengendalian Diri (Self Regulation). Pengendalian diri santri Pesantren Luhur ditandai dengan adanya sifat sifat kehatihatian, mudah beradaptasi dengan masyarakat sekitar pesantren dan masyarakat umum.

3) Motivasi (Motivation), ditandani dengan adanya dorongan untuk berprestasi, memiliki komitmen, memiliki Inisiatif, bersikap Optimisme. Hal ini sesuai dengan motto dan slogan yang ada di Lembaga Tinggi Pesantren Luhur Malang yang selalu diucapkan oleh pengasuh pesantren setiap saat dalam kegiatan pesantren. Motto dan slogan tersebut adalah:

a. Triple Co (co ownership, co determinate, dan co Responsibility,) Adapun makna dari slogan triple co adalah adalah setiap santri harus bertanggungjawab terhadap pesantren, terhadap agama, terhadap Allah dan rasul-Nya dan terhadap dirinya sendiri,merasa memiliki sehingga menjaga,dan menentukan atau punya inisiatif untuk melakukan hal yang baik.

b. "Hum rijaalun wa nahnu" yo "rijaalun". Slogan ini berasal dari bahasa Arab dan bahasa Jawa yang artinya "mereka lakilaki kita " yo "laki-laki ", kalau mereka mampu mengapa kita tidak, mengingat kita adalah sama yaitu manusia yang sama-sama diciptakan oleh Allah SWT. 
Hal ini merupakan sifat optimis yang akan selaludimiliki oleh santri dalam melaksanakan setiap aktifitas untuk mencapai kehidupan yang lebihbaik. adanya slogan ini para santri selalu berusaha untuk meraih cita-citanya dalam dunia dan cita-cita di akhirat, dengan semangat cinta kepada Allah.

4) Empati (Emphaty), sifat empati merupakan perilaku yang ditandai dengan memahami orang lain, mengembangkan orang lain, memiliki orientasi pelayanan, mampu memanfaatkan keragaman. Dalam hal ini pesantren luhur yang dihuni oleh beberapa santri dari berbagai perguruan tinggi dan berbagaio fakultyas serta jurusan akan saling memebrikan informasi melalui halaqoh dengan judul yang berbagai lintas disiplin keilmuan. Adanya keragaman ini akan dimanfaatkan oleh santri untuk saling menghargai, memahami orang lain, dan memanfaatkannya untuk mendapatkan makna-makna yang positif dari setiap keragaman yang ada.

5) Ketrampilan Sosial (Social Skills), yang ditandai dengan memiliki pengaruh, membangun komunikasi dengan baik, mampu memanajemen konflik, memiliki kemampuan memimpin, menjadi katalisator perubahan, membangun hubungan, kolaborasi dan kooperasi, dan memiliki kemampuan tim. Adanya slogan tiple co tersebut diatas tentunya akan membuat santri pesantren Luhur memiliki keterampialn social yang tinggi apabila motto tersebut diatas benar-benar diterapkan tidak hanya di pesantren, tapi seelah mereka kelaur dari pesantren.

\section{PENUTUP}

Berdasarkan penelitian tersebut diatas, menunjukkan bahwa terdapat beberapa faktor yang membantu santi di lembaga pesantren luhur yang membantu mereka untuk mengembangkan kecerdasan emosional dan spiritual. Selain beberapa kegiatan tersebut motto dan slogan yang ada pada pesantren juga memiliki pengaruh besar dalam membantu santri untuk mengembangkan kecerdasan emosional dan spiritualnya.

Adapun kegiatan yang membantu santri untuk mengembangkan kecerdasan emosional dan spiritual yaitu JQH, dan FORKAFI, diamana
JQH dan FORKAFI ini membentuk mahasantri yang menghafal, memahami makna dan menjalankan isi dari Al-qur'an, sehingga bermanfaat bagi agama, nusa dan bangsa. Diharapkan dengan memahami dan menjalankan isi yang ada dalam al-Qur'an maka itu akan menjadi penuntun dalam menjalankan tanggung jawab dalam kehidupan sehari-hari, karena dalam al-Qur'an dianjurkan untuk berlaku jujur dan melakukan pengabdian kepada masyaraka. Selain itu santri juga akan memiliki kesadaran terhadap dirinya sendiri, memiliki visi, bersikap fleksibel, berpandangan holistik, melakukan perubahan, menjadi sumber inspirasi, dan mampu refleksi diri sendiri.

Sementara untuk kecerdasan emosional adalah dengan kegiatan halaqoh. Kegiatan halaqoh ini dengan memberikan beberapa materi lintas disiplin ilmu yang mana dalam materi tersebut akan memberikan pemahaman keilmuan yang menyeluruh sehingga setiap santri akan memiliki satu kesatuan kemampuan emosional dan personal, yang mana dalam materi tersebut diatas sangat relevan dengan kehidupan seharihari.

\section{DAFTAR PUSTAKA}

Azra, A. (1997). Konstruksi agama memasuki millennium ketiga. Jurnal PERT, DitbinpertaDepag Pusat dan PPIM IAIN Jakarta, Vol 1, No.1 September 1997

Djamil, A. (1999). Pesantren dan kebudayaan, kajianulang tentang pesantren sebagai pembentuk kebudayaanindonesia. Semarang: IAIN Walisongo

Ginanjar, A. (2005). Rahasia sukses membangun kecerdasan emosi dan spiritual berdasarkan 6 rukun iman dan 5 rukun islam. Jakarta: Arga.

Ginanjar. A. (2008). Rahasia sukses membangun esq power, sebuah inner journey melalui ihsan. Jakarta: Penerbit Arga.

Goleman, D. (2006). Kecerdasan emosional: mengapa EI lebih penting dari IQ. Jakarta: Gramedia Pustaka Utama

Goleman, D. (1999). Kecerdasan emosi untuk mencapai puncak prestasi (working with emotional intelligence). Jakarta: PT. Gramedia Pustaka Utama.

Goleman, D. (2005). Working with emotional intelligence: kecerdasan emosi untuk mencapai puncak prestasi. Alih Bahasa: oleh Alex Tri K. Widodo. Jakarta: PT Gramedia

Hasbullah. (1999). Sejarah Pendidikan Islam di Indonesia:Lintasan Sejarah Pertumbuhan dan 
Perkembangan, PT Raja Grafindo Persada, Jakarta, (hl 24-27, 138-161)

Leny, J. (2006) Mengembangkan kecerdasan spiritual anak. On-line: http://www.mail-archive.com Akses (06-12-09)

Lynn, A.B. (2002). The emotional intelligence activity book: 50 activities for promoting eq at work. New York

Nggermanto, A. (2001). Quantum quotient (kecerdasan quantum): cara cepat melejitkan iq, ie, dan sq secara harmonis. Bandung: Nuansa

Madjid, N., (1997). Bilik-bilik pesantren, Jakarta: PT. Paramadina,

Mayer, J.D., Ciarrochi, J., Forgas, J.P. (2001). Emotional intelligence in everyday life: a scientific inquiry. London: Nasional Gallery.Mudali, (2002). Quote: how high is yous spiritual intelligence? http://www.eng.usf.edu/gopalakr/artcles/spiritua 1.html, 15 Juni 2005

Patton, P, (1998), Kecerdasan emosional di tempat kerja. Alih Bahasa : Zaini Dahlan, Pustaka Delaprata, Jakarta

Partanto, A. P., \& Al-Barry, M. D. (1994). Kamus Ilmiah Populer. Surabaya: Arkola

Qomar, M. (2006). Pesantren (dari tranformasi metodologi menuju demokrasi instrusi). Jakarta: Erlangga

Segal, J. (2000). Melejitkan kepekaan emosional. Bandung: Mizan Media Utama

Setiadi, A. V. A. (1999). Hubungan antara kecerdasan emosional dengan keberhasilan bermain game. Skripsi (tidak diterbitkan). Fakultas Psikologi Universitas Surabaya, Surabaya.

Sudarsono. (1993). Kamus filsafat dan psikologi, Jakarta: Rineka Cipta

Wahab, A., \& Umiarso. (2011) Kepemimpinan pendidikan dan kecerdasan spiritual, Jogjakarta: Ar-Ruzz Media

Wahid, Abdurrahman., (2001). Menggerakkan Tradisi: Esai-Esai Pesantren, LkiS, Yogyakarta..

Yosep, I. (2005). Pentingnya ESQ (emosional \& spiritual quotion) bagi perawat dalam manajemen konflik. disampaikan pada cerdas, kreatif, berwawasan dan mandiri (cerebri) kegiatan penerimaan mahasiswa baru fakultas ilmu keperawatan unpad: Bandung

Zohar, D, Marshal, I, 2000, SQ (spiritual intelligence) : The Ultimate Intelligence, Blomsburry Publishing, London

Zohar, D. \& Ian Marshall. (2002). SQ memanfaatkan kecerdasan spiritual dalam berfikir integralistik dan holistik. Bandung: Mizan Pustaka.

Ziemek, M., (1986). Pesantren Dalam Perubahan Sosial, Jakarta.

Zuhairini, et.al (1997). Sejarah Pendidikan Islam, Bumi Aksara, Jakarta. 